\title{
THE AFTERLIVES OF SPECIMENS: WALT WHITMAN AND THE ARMY MEDICAL MUSEUM
}

\author{
LindsAy TUGgLE
}

In December 1862, the poet Walt Whitman and the surgeon John Brinton arrived separately at Falmouth, Virginia, in the aftermath of the Battle of Fredericksburg. Whitman had travelled from Brooklyn in search of his brother, George, who was listed as a casualty. While Brinton scavenged the field hospital's medical waste in search of specimens for the Army Medical Museum, Whitman found George alive and relatively unscathed - a shell fragment had grazed his cheek, but he suffered no lasting damage. The poet remained at camp for two weeks, crystalizing the devotion to wounded soldiers that would dominate his life for the duration of the war, and well beyond. ${ }^{1}$ Whitman spent the remaining war years as a constant presence at the bedsides of soldiers in the Washington hospitals, even to the detriment of his own health. ${ }^{2}$ Irrevocably altered by these encounters with wounded and dying men, he endeavored to preserve their "spiritual character" within his poetry and prose. ${ }^{3}$

This article examines previously unrecognized symmetries between Whitman's hospital reminiscences and those of Brinton, founding curator of the Army Medical Museum. The two men led convergent lives during the war years, beginning with their mutual presence at Falmouth. Given the probability that they crossed paths at Armory Square Hospital (where both were frequent visitors, at least once at the bedside of the same man), my findings are significant not only to Whitman studies, but also to Civil War medical and military histories. Through the entwined narratives of Whitman's Memoranda During the War (1875) and the Personal Memoirs of Fohn H. Brinton, Civil War Surgeon, 1861-1865 (published posthumously in 1914), I explore the shrinking distinction between the human body as object of mourning and subject of scientific enquiry during the Civil War. Placing Memoranda alongside psychoanalytic frameworks of incorporation, I also analyze the hospitality of anonymous mourning and the cultural anxiety resonant around the unburied dead. This collective trauma reflects a dual ambiguity that was deeply troubling to Whitman: the anonymity of the dead and the absence or unlocatability of their graves. 
Whitman inhabited a landscape of diverse mourning cultures, navigating elaborate rituals that governed interactions between the living and the dead. Antebellum anatomists, elegists, spiritualists, and mourners shared a collective fascination with the cadaver that dominated the nineteenth century. The deathbed vigil became an unbridled spectacle in antebellum society and a dominant literary device. Mourning manuals read like etiquette books mandating ornate funeral ceremonies. Jewelry containing locks of hair or images of the deceased served as tokens of ongoing devotion. Demand for posthumous photographs soared as the camera became an increasingly accessible medium. The emerging faith of Spiritualism sought to continue contact with the dead beyond the grave. ${ }^{4}$

During the war, the chronic shortage of cadavers available for anatomical dissection was temporarily suspended. ${ }^{5}$ Seemingly overnight, battlefield carnage transformed human bodies from rare commodities, usually obtained illegally, into abundant specimens readily available for the taking. The corpses of soldiers were appropriated by surgeons, embalmers, curators, and photographers; these bodies and limbs were manipulated, altered, and arranged to suit the particular purposes of the collector's context. Curiosity about the consequences of battle saw corpses exhibited for public consumption long after death and dismemberment. Photographers such as Mathew Brady and Alexander Gardner published wildly popular collections of battlefield scenes, while thousands viewed the human remnants on display at the new Army Medical Museum. ${ }^{6}$ The specimen-soldier occupied the space between science and sentiment, the historical moment of convergence at which the human cadaver was both lost love object and subject of empirical anatomical violence.

Memoranda During the War documents the psychosomatic aftermaths of trauma - the embodiment of mourning through the recurrent pain of "old, lingering wounds" (MDW 38). Whitman sought to salvage the war's "human fragments" - to textually preserve the "animal purity" of their broken bodies. ${ }^{7}$ The word "trauma," drawn from the Greek term for a physical wound, signifies not only an "external body injury," but also a "psychic injury" resulting from "emotional shock, the memory of which is repressed and remains unhealed." "Sigmund Freud emphasized the magnetism of melancholia, which "draw [s] to itself cathectic energies . . . from all directions." This melancholic appropriation of psychic energy parallels Whitman's paradoxical attraction to the hospitals. The wards exerted a mesmeric hold over the poet, revealing to him "the most magnetic as well as terrible sight[s]."10

Conceptualizing melancholia as a psychic lesion, Freud and Josef Breuer captured the open-ended allure of the unhealing wound. They described the "memory of the physical trauma" as a "foreign body" 
lodged within the mind, continuing to wreak havoc "long after its forcible entrance." ${ }^{11}$ This conception of trauma as both open wound and embedded shrapnel correlates with the Army Medical Museum's mandate to collect artifacts demonstrating both unusual wounds and the projectiles removed from them: "medical officers are directed diligently to collect ... specimens of morbid anatomy. . . together with projectiles and foreign bodies removed . . . as may prove of interest in the study of military medicine or surgery." 12 While the overt goal of the museum was to preserve artifacts of "lasting scientific interest," it operated within the "pathological public sphere" as a phenomenon that Mark Seltzer has described as an "atrocity exhibition."13 This medical spectacle catalyzed "a fascination with the shock of contact between bodies and technologies," appealing to a public captivated by the human cost of recent innovations in weaponized warfare (Seltzer 3). ${ }^{14}$

"As soon as the Museum was fairly established," Brinton wrote, "it began to attract attention. The public came to see the bones, attracted by a new sensation" (PM 189). Brinton's repeated use of the verb "attract" to describe the gravitational pull of this "new sensation" speaks volumes about the museum's popularity. Visitors were drawn "to see the bones," their gaze held by specimens originating from the convalescent tableaus that captivated Whitman. Unlike Whitman's devotion to living soldiers, the Army Medical Museum evokes a quarantined, posthumous voyeurism. These medical specimens are enclosed within cases that prevent them from contaminating the living. The exhibition is not only sensational, it is also, Brinton emphasizes, new. The Medical Museum operates as an early example of Seltzer's "wound culture," in which "the very notion of sociality is bound to the excitations of the torn and opened body, the torn and exposed individual, as public spectacle" (Seltzer 3-4). I interrogate the Army Medical Museum as a cabinet of anatomical curiosities that exemplifies post-bellum America's preservation compulsion. Brinton's memoirs enact a collective suturing function. The curator inscribes a medical mandate onto the war's disparate fragments. The Army Medical Museum enshrines the sources of trauma-extracted projectiles-alongside remains of the human bodies they shattered. Brinton merges foreign, military, and human bodies to create a unionist narrative of the war's medical legacy. Yet, as we shall see, his is also an account of pathological detachment, in which the human body is repeatedly subjected to anatomical invasions and exhibitions, often without consent and at times in direct conflict with the soldier's expressed wishes.

Whitman's convalescent soldiers are often described as "specimens," fusing his interest in scientific classification with an intimate form of observation. The term is etymologically grounded in voyeurism. The Latin root, specere, literally means "to look or behold" (OED). 
In another sense, it refers to a representative human, animal, plant, or mineral which serves as an example of the thing in question for purposes of investigation. Reflecting on the influx of the wounded into the Washington hospitals, the poet casts these men as emblems of democracy:

[I]n my recollections of that period, and through its varied, multitudinous oceans and murky whirls, appear the central resolution and sternness of . . the average American People, animated in Soul by a definite purpose ... emblemised in thousands of specimens of first-class Heroism. . . . [T]o me the main interest of the War, I found . . . in those specimens ... embodied in the armies-and especially the one-third or one-fourth of their number, stricken by wounds or disease . . . were of more significance even than the Political interests involved. (MDW 4-5)

Through the "murky whirls" of memory, Whitman's specimens emerge as dual archetypes of the "average American" "Soul" and the exceptional "Heroism" "embodied in the armies." As an incarnation of the fractured union and the fragmented body, they represent "countless" fallen soldiers (3). Whitman remained haunted by the anonymous dead, those who were "inhumed by strangers," lay nameless in mass graves, or remained where they fell, "unburied and unknown" $(56,16)$. Their deaths eclipse all other consequences, as though the entire war was waged upon the specimen as "emblem" of the democratic body: "Not Northern soldiers only ... many a Southern face and form, pale, emaciated, with that strange tie of confidence and love between us, welded by sickness, pain of wounds" (3-4). This "strange tie" of mutual suffering "weld[s]" together "representatives" from across the divided states. The whole (union) is signified by one of its parts - the genus is named for the species. The specimen embodies the synecdoche of the stranger: an anonymous other capable of absorbing the diversity of war casualties. ${ }^{15}$

The presence of specimens endures throughout Whitman's postbellum work. He even titled his autobiography, which was largely devoted to the war, Specimen Days (1882). ${ }^{16}$ Yet there has been little sustained analysis of the phenomenon of specimen collection across the Whitman canon. Mark Feldman has suggested that Whitman's specimens are objects on textual display, not unlike the cabinets of curiosity popular in nineteenth-century museums and the homes of private collectors. ${ }^{17}$ Adam C. Bradford has argued that these collections actively resist the commodification and devastation of human bodies endemic to war: "selecting those soldier specimens he could use most productively to represent the war," Whitman creates a "psycho-textual space where he could ensure the appreciation of human value."18 I explore the significance of the specimen as remnant: a partiality that evokes a form of mourning which is both embodied and anonymous. ${ }^{19}$ In the Army Medical Museum, the specimen is a detached part of a specific body, 
preserved from decay and bearing no visibly-discernable identifying markers. Divorced from its "original possessor," the museum specimen attains a form of corporeal immortality; it becomes, in Brinton's words, a relic of "lasting scientific interest" (PM 186). ${ }^{20}$ I examine the intersection between these two methods of collection (medical and poetic), yet unlike Feldman I find that Whitman radically departs from the medical museum model of dehumanization. For Whitman, the war's "human fragments" epitomize the enduring sublimity of the body. Traces of its "spiritual character" endure beyond death and dismemberment (NUPM $2: 504 ; M D W 27)$. I analyze the Whitmanian specimen as the material and psychic remains of the dying soldier: a synecdochic figure that facilitates the symbolic burial of countless inaccessible bodies.

The arrival of the Civil War ruptured the panoramic inclusiveness of Leaves of Grass, fundamentally altering Whitman's understanding of nationalism, and the function of his text within the cultural landscape. In the preface to "Good-Bye My Fancy" in the "Deathbed edition" (1891-2), Whitman described the war's impact on his lifelong project:

[T] hose hot, sad, wrenching times ... the wounded, suffering, dying ... those hecatombs of battle-deaths - Those times of which, $\mathrm{O}$ far-off reader, this whole book is indeed finally but a reminiscent memorial from thence by me to you[.] $]^{21}$

The post-bellum structure of Leaves of Grass echoes the psychic resurrection of trauma - an event so arresting that it is never "fully known and is therefore not available to consciousness until it imposes itself again, repeatedly, in the nightmares and repetitive actions of the survivor." 22 Whitman's incessant revisions function as elements of a repetition compulsion, made manifest by his own experience as witness to war atrocities. Poems were repeatedly clustered, altered, or expelled in the author's quest for an elusive body of work that could function as a "reminiscent memorial." This "compulsion to repeat" through the evolution of poetic work speaks to the fundamental dissonance of traumatic experience: the possibility of pleasure through suffering. ${ }^{23}$

\section{Phantoms of Countless Lost}

The frequency of Civil War amputations led to an epidemic of phantom limbs, a diagnostic term coined by Whitman's post-war physician and Brinton's colleague, Silas Weir Mitchell, in $1871 .{ }^{24} \mathrm{He}$ debuted this neurological theory in an article detailing the post-amputation phenomenon he described as a "sensory ghost." ${ }^{25}$ In January 1864, Whitman witnessed the amputation of Lewis K. Brown's left leg. During the preceding sixteen months at Armory Square Hospital, Brown had become Whitman's close friend, and quite possibly his lover. ${ }^{26}$ Chief Surgeon Willard Bliss 
amputated Brown's leg just below the knee, while Whitman observed from the doorway: "I could hear his cries . . . and caught glimpses of him through the open door." The poet documented the neurological consequences of this severance: "[Lewy] could feel the lost foot \& leg very plainly. The toes would get twisted, \& not possible to disentangle them" (NUPM 2:669). He included similar scenes of amputation in "The Dresser" (1867):

From the stump of the arm, the amputated hand,

I undo the clotted lint, remove the slough, wash off the matter and blood[.] ${ }^{27}$

Phenomenologically, the phantom limb manifests as a physical presence felt most acutely in its absence. This neurological nostalgia parallels Whitman's melancholic drive to textually preserve specimens. As Michael Moon observes, Whitman narrates "desire(s) of or for bodies that are no longer capable of being perceived as whole, 'healthy,' and labile." ${ }^{28}$ This reverence toward partial bodies demonstrates an attachment to the process of loss, through which profound intimacies are formed. Whitman's libidinal investment in amputees mirrors his poetic fascination with erotic-linguistic vacancy. Memoranda's specimen "cases" borrow from contemporary botanical and medical rhetoric to chart the evolution of a unique category of "beings" ( $M D W 48)$. As Robert Roper explains, "Walt and other men and women of the last half of the nineteenth century were aware of a lack of terminology for describing a way of being they felt themselves, sometimes, in whole or in part, to embody" (45). The term "homo-sexual" first appeared in English in a translation of Krafft-Ebing's Psychopathia Sexualis in 1892, the year of Whitman's death. The poet's appropriation of words such as phrenological "adhesiveness" for masculine same-sex desire, "specimen" for subject of erotic curiosity, and "comrade" for lover or friend, comprised an attempt to construct a nomenclature that could fill that void. Memoranda's collected observances represent an epistemological study in keeping with Michel Foucault's historicity of homosexuality: “The nineteenth-century homosexual became a personage, a past, a case history, and a childhood, in addition to being a type of life, a life form, and a morphology, with an indiscreet anatomy and possibly a mysterious physiology." ${ }^{29}$ Whitman offers a unique perspective on the evolution of this anatomy: he views queer morphology through reverential, rather than diagnostic, eyes. In the context of his hospital work, this sense of queer unspeakability operates at the threshold of contemporary medical investigations. Just as the phantom limb preserves a sensory link to the lost part, Whitman experienced enduring nostalgia for the hospitals: 
Thus in silence, in dreams' projections,

Returning, resuming, I thread my way through the hospitals;

The hurt and wounded I pacify with soothing hand,

I sit by the restless all the dark night - some are so young;

Some suffer so much-I recall the experience sweet and sad;

(Many a soldier's loving arms about this neck have cross'd and rested,

Many a soldier's kiss dwells on these bearded lips.)

(LG 1867, 33a-34a)

Like the ghostly pains of the amputee, Whitman inevitably returns, "in dream's projections," to the hospital corridors. The poet seeks to psychically resurrect soldiers' abandoned bodies and detached parts. The phantom limb is literally an untouchable extension, a neurological trace of the lost object. This elegiac rendering of the deathbed scene evokes a similarly impossible touch: the revivification of a dying man's kiss.

The reciprocal fidelity of convalescence rejects hetero-normative assumptions that sexuality is negated by partiality. Whitman highlights the loyalty of the wounded toward their "dresser": "I have come to adapt myself to each emergency ... washing and dressing wounds, (I have some cases where the patient is unwilling any one should do this but me)" (MDW 31). For the self-proclaimed "poet of the Body," the wound occupies a space of heightened sensation, inhabiting the borderland between interior and exterior, mortality and spirit ( $L G$ 1891, 45). Eve Kosofsky Sedgwick elucidates a theoretical paradox around such corporeal enclaves of vacancy: "erotic localization has most the effect of voiding - of voiding by so exceeding it - the very possibility of erotic localization. ... [T] he neat dichotomy of 'active' and 'passive'... renders as an organ of this sexuality the whole cutaneous envelope of the body." 30 Whitman figures the wound as a space of heightened immersion, home to an eroticism that transcends physicality by spectacularly eclipsing it. Within this threshold, suffering acts as a portal for "animal purity," catalyzing the transition from flesh to spirit:

Every now and then in Hospital or Camp, there are beings I meet-specimens of unworldliness, disinterestedness and animal purity and heroism ... the power of a strange, spiritual sweetness. .. . Something veil'd and abstracted is often a part of the manners of these beings. ... They are often young men . . . unaware of their own nature ... their companions only understanding that they are different from the rest, more silent, "something odd about them," and apt to go off and meditate and muse in solitude. (MDW 27-28)

Whitman's specimens exist within a class all their own, members of some higher order of "beings." There is something already spectral, "veil'd and abstracted," about their presence, which haunts the poet in advance of their actual deaths. The specimen epitomizes the intimacy that passed 
between strangers in the hospital wards. Oddness is an integral aspect of his character, an uncanny articulation of queer specificities that render the subject "unworldl[y]." This strange entity not only resists mortality, his presence somehow transcends the material world. The specimen offers a queer alternative to ritualized mourning practices dominated by elaborate funerary traditions. Its mourners do not require a body, or even part of a body, to situate their loss. Through the textual preservation of this ephemeral being, infinite others can be absorbed.

While the war shattered Whitman's vision of a cohesive Union, its soldiers embodied his "Calamus" ideal of "the manly love of comrades" (LG 1891,99). The calamus plant was traditionally used in naturopathy as a balm for "slowly healing wounds." ${ }^{11}$ In Botanologia (1710) William Salmon recommended calamus as a cataplasm: "applied to the Testicles, it wonderfully abates their Swelling." ${ }^{32}$ Whitman would have been aware of these medicinal properties. As Maria Farland has demonstrated, "Whitman's medical philosophy was deeply rooted in a set of ideas linked to naturopathic and herbal healing." ${ }^{33}$ The poet applies his "Calamus" principles of "adhesiveness" as a curative salve, an act that is highly subversive and erotically charged:

I dress a wound in the side, deep, deep;

But a day or two more-for see, the frame all wasted and sinking,

And the yellow-blue countenance see.

[...]

I am faithful, I do not give out;

The fractur'd thigh, the knee, the wound in the abdomen,

These and more I dress with impassive hand-(yet deep in my breast a fire, a burning flame.) ( $L G 1867,33 a)$

Many of Whitman's war texts are meditations on the paradoxical pleasures of tending unhealing wounds, recalling Freud's assertion that melancholia "behaves like an open wound" that seeks to fill itself entirely with absence (MM 262). For Freud, melancholic incorporation reflected an incapacity to conclude the processes of mourning. Rather than productively "working through" bereavement for the lost other, the subject absorbs the loss itself, creating an intrinsic homage to trauma that lives within the survivor. Maria Torok and Nicholas Abraham's conception of incorporation actively resists the finality of mourning. Torok and Abraham divided the primary mechanism behind mourning ("internalization") into two subsets: "introjection," the process of symbolically absorbing the absent other, and "incorporation," the fantastic wound of melancholia in which the totality of loss remains unrealizable and the other is encrypted within the psyche. ${ }^{34}$ Like the absent presence of the phantom limb, the traumatic vacancy of melancholia can never 
be filled. This interior lesion remains not only open, but insatiable: a "foreign body" embedded within the psyche that continually attracts libidinal investment. As Christopher Peterson has observed, "the Freudian paradigm ... pathologizes any deviation from the supposedly finite process of mourning." 35 The binary between "successful" (temporary) grief and unending melancholia depends on the theory that substitution of a new love object can abate traumatic rupture. The melancholic refuses to divest attachment from the absent other, denying the act of cathectic replacement that would end the "work" of mourning ( $M M$ 244). In keeping with Whitman's "unending, universal mourning," Jacques Derrida famously revised melancholic resistance as an act of revolutionary "fidelity" toward the dead. ${ }^{36}$ For Derrida, the "unbearable paradox" of mourning dictates that in order to maintain the other's alterity, psychic absorption must remain incomplete. Derrida's ethos of reciprocal haunting echoes Whitman's literary conjurations: "an open hospitality to the guest as ghost, whom one holds, just as he holds us, hostage." ${ }^{37}$ In "Ashes of Soldiers" (1865), Whitman invites "Phantoms of countless lost" to remain his constant "companions": "Invisible to the rest henceforth become my companions, / Follow me ever-desert me not while I live" ( $L G 1891,372$ ). Yet, Whitman does not rely solely on psychic internalization of the dead. Moving beyond the grave as the designated site of haunting, Leaves of Grass is reconfigured as a "reminiscent memorial" to which infinite losses are attached $(L G 1891,408)$.

In the hospitals' convalescent spaces, through acts of hospitality to dead and dying men, Whitman experienced profound loss, but also heightened attachments to liminal beings, those on the threshold between life and death. ${ }^{38}$ These encounters were all the more lasting for their ephemerality, and all the more pleasurable for their juxtaposition with intense pain: "I believe no men ever loved each other as I \& some of these poor wounded, sick \& dying men love each other." ${ }^{39}$ In the absence of burial for many fallen soldiers, Whitman devised an alterative method for mourning the dead-the specimen is interred within the book, resurrected whenever its pages are opened:

I can never turn their tiny leaves . . without the actual army sights and hot emotions of the time rushing like a river in full tide through me. Each line, each scrawl, each memorandum, has its history. ... Out of them arise active and breathing forms. They summon up, even in this silent and vacant room as I write, not only the sinewy regiments and brigades ... but the countless phantoms of those who fell and were hastily buried by wholesale in the battle-pits, or whose dust and bones have since removed to the National Cemeteries of the land. $(M D W 3)$

Whitman's response to these "tiny leaves" goes beyond the provocation of a traumatic flashback. "[L]iving" beings "arise" from the pages, 
bringing with them the "actual" "sights" and "emotions of the time." The book acts as medium for a collective haunting, home to "countless" "phantoms" whose "dust and bones" were relocated to the National Cemeteries. The exhumation and reburial of their bodies reflect the diasporic afterlives of Civil War specimens.

Throughout his hospital visitations, Whitman recorded soldiers' case histories: "I kept little note-books for impromptu jottings in pencil. ... In these I brief'd cases, persons, sights, occurrences in camp, by the bedside, and not seldom by the corpses of the dead." The notebooks resist narrative coherence, forming instead a collage of details that might otherwise be forgotten. Their pages recall the last words of soldiers and the resonant silence of the dead, whose bodies would become the war's most "eloquent bequest" (PP 1210). Whitman describes the notebooks as blood relics of history:

[F] orming a special history of those years, for myself alone, full of associations never to be possibly said or sung. I wish I could convey to the reader the associations that attach to these soil'd and creas'd little livraisons, each composed of a sheet or two of paper, folded small to carry in the pocket, and fasten'd with a pin. I leave them just as I threw them by during the War, blotch'd here and there with more than one blood-stain, hurriedly written ... (MDW 3$)$

This text holds an incantatory power because it retains the sense of partiality in which it was composed. ${ }^{40}$ Whitman's journals are emotive conduits into the traumatic urgency of the past: "Vivid as life, they recall and identify the long Hospital Wards ... the convulsive memories, (let but a word, a broken sentence, serve to recall them)." Like the flashbacks they invite, the books are both "convulsive" and fractured: their words are "broken," their pages linked only by a pin. The notebooks form a "special history" known only to the poet, containing "associations" that defy representation, "never to be possibly said or sung" $(M D W 4,3)$.

The impossibility of literary representation mirrors the psychological manifestation of trauma, an experience so sudden and shattering that it cannot initially be fully integrated. ${ }^{41}$ Whitman's revisions function as elements of a repetition compulsion, allowing him to return, "in dream's projections," to the hospital corridors. ${ }^{42}$ Each incarnation of the war text is an act of incorporative mourning. The bloodstained original is absorbed into the latest work, slightly altered with each retelling. Whitman's halting prose mirrors the elusive magnetism of trauma. It is not easily integrated into a linear narrative. Its ghosts arrive without warning, arising from the pages, "vivid as life" $(M D W 4)$. Even the act of writing evokes violence, as does the method of creating the book: the words are "scratch'd," the pages sutured with a pin. ${ }^{43}$ As a discourse on the psychosomatic resonance of trauma, Memoranda During the War 
occupies a position of startling contemporary relevance, not only to literary representations of history, but also to issues of legacy, mourning, and the inherent unknowability of the casualties of war.

\section{Human fragments, Ghoul-like work}

John Hill Brinton volunteered with the surgical brigade in August 1861. Within a year, he was reassigned to the Surgeon General's Office, where his primary duty was "to prepare the Surgical History of the Rebellion" (PM 169). On August 1, 1862, Brinton was directed by Surgeon General William A. Hammond to establish a museum devoted to "specimens of morbid anatomy" (180). This was the beginning of a collection that would incorporate thousands of Civil War remains, many of which are still on display at the National Museum of Health and Medicine.

Brinton soon found himself entrenched in a "ghoul-like duty," responsible for the procurement of anatomical artifacts "portraying the results of wounds, operations, or peculiar amputations" $(8) .{ }^{44} \mathrm{He}$ travelled to hospitals and battlefields in search of specimens, sometimes exhuming bodies from their graves in order to obtain the desired part. He instructed surgeons on the best methods of preservation: how to pack limbs in kegs of alcohol and arrange their safe transportation to Washington. Brinton regarded the curatorship as his greatest professional achievement, stating simply, "My whole heart was in the Museum. . . . By it the results of the surgery of this war would be preserved for all time" (181). Reflecting on his war service decades later, the curator nostalgically inserted a part of himself into the anatomical collection. His heart is incorporated within the museum, devoted to ensuring the war's surgical legacy.

Brinton's rhetoric reflects a culture of preservation that began during the war and flourished in the aftermath of Lincoln's assassination. The museum infused dissected matter with national significance, in an effort to counter the symbolic dismemberment of the Union. The preservation of the body, by whatever means necessary, became of paramount importance during the Civil War. In the space of a few decades, anatomical dissection evolved from a posthumous punishment enacted on the bodies of stolen, executed, or unclaimed cadavers, to an element of preservationist technology worthy of the presidential corpse. The extended public display of Abraham Lincoln's body was made possible by recent innovations in embalming, which was often practiced on the bodies of unknown soldiers. ${ }^{45}$ The human remains displayed at the Army Medical Museum paved the way for the publication of graphic details of Lincoln's cranial autopsy, a phenomenon that would have been unthinkable even a decade earlier. Lincoln eventually joined the ranks of specimens whose case histories were detailed in the six-volume 
Medical and Surgical History of the War of the Rebellion (1870-1883). The museum was relocated to Ford's Theatre in 1866, securing Lincoln's status as America's most sacred democratic specimen. ${ }^{46}$

In the opening pages of his memoir, Brinton frames the crisis of the Union in terms of preservation: "the problem was how to preserve the unity and majesty of the Nation, and how soonest to trample out the doctrines of disintegration and 'secession"' (PM 15). The surgeon's preservation compulsion entails not only an anatomical agenda, but also a patriotic impulse. Brinton created a coherent medical narrative of war, reflecting a nation that conserved the "rejected members" of its citizens. ${ }^{47}$ The Army Medical Museum echoed the unionist ideology that decay of the wounded democratic body could be arrested, that amputation of the secessionist states was not the only option.

Amputation was perhaps the Civil War's most gruesome medical legacy. "The limbs of our friends and countrymen," wrote Oliver Wendell Holmes, "are part of the melancholy harvest which War is sweeping down." ${ }^{\prime 48}$ That violent reaping severed the extremities of some 60,000 soldiers. Civil War projectiles shattered bones and destroyed surrounding tissue so totally that surgeons were often left with no alternative to amputation. ${ }^{49}$ Almost two-thirds of Civil War deaths resulted from infection and disease. The hospital wards were, in their way, every bit as dangerous as the killing fields. Absent any medical understanding of sepsis and germ theory, the cure was often as deadly as the cause.

Arriving in Falmouth on December 19, 1862, Whitman was immediately confronted with the medical detritus of war. The poet recorded his horror at the "terrible spectacle" of the "dead and living burial-pits" surrounding the camp: "Out doors, at the foot of a tree, within ten yards of the front of the house, I notice a heap of amputated feet, legs, arms, hands, \&c., a full load for a one-horse cart." This image describes the field hospital at Lacy House, where surgeons dropped severed limbs from windows near the makeshift operating tables. The limbs fell at the base of a catalpa tree below, and were eventually buried in mass graves $(M D W 7,57,6)$.

Brinton may have sifted through this same pile in search of museum specimens. By the time Whitman entered the scene, the curator was already an established presence in the field hospital, having arrived six days earlier on December 13. While both men were compelled to care for the wounded, Brinton also searched the surgical debris, "to preserve for the Museum," the "mutilated limbs" that, without his intervention, "were usually buried in heaps." The curator described the nationalistic fervor of his efforts as "infectious": "many a putrid heap have I dug out of trenches where they had been buried, in the supposition of an everlasting rest, and ghoul-like work have I done, amid surrounding gatherings of wondering surgeons. .. . But all saw that I was in earnest 
and my example was infectious" (PM 187). Brinton appropriates the viral rhetoric of infection to describe his preservationist mandate. As a medical "resurrectionist," he subverted the "everlasting rest" of burial, in favor of a public afterlife in the museum. ${ }^{50}$

The spectacle of discarded limbs outside Lacy House endured as a traumatic afterimage in Whitman's memory. In a letter to his mother, he described this scene of dismemberment as "one of the first things that met my eyes in camp." ${ }^{51}$ In his field diary, Whitman again reflected on the "Sight at the Lacy House": "human fragments, cut, bloody, black and blue, swelled and sickening - in the garden near, a row of graves" (NUPM 2:504-505). As a visual legacy, the afterimage returns unbidden, an optical ghost that appears long after the original exposure has ceased. The resonance of this initial encounter foreshadows Whitman's fascination with amputation as a signifier of the wound's erotic vacancy, and his continued reverence toward the war's casualties and their detached parts. As the wounded languished in camp hospitals, Whitman began the bedside ministrations that would consume him for the remainder of the war:

I do not see that I do much good, but I cannot leave them. Once in a while some youngster holds on to me convulsively, and I do what I can for him; at any rate, stop with him and sit near him for hours, if he wishes it. (MDW 7$)$

Whitman's description of the soldier's "convulsive" embrace demonstrates the permanence of his ties to the men he attended. ${ }^{52}$ However immaterial he perceives his presence to be, he is incapable of leaving them behind. Memoranda During the War charts the poet's vast alteration through the hospitality of merging with another's wound. From his earliest war entries, Whitman insists that the body need not be whole, or even alive, in order to be adored..$^{53}$

\section{Specimens of Unworldliness}

When he departed Falmouth on December 28, 1862, Whitman accompanied a convoy of wounded soldiers bound for Washington. Upon arrival, he established residency in the capital as a "self-appointed Soldier's missionary." ${ }^{4}$ The poet devoted his considerable energies to the hospitals, tending, by his own estimation, "80,000 to 100,000 of the wounded and sick, as sustainer of spirit and body" (MDW 56). From October 1861 until March 1863, the Patent Office relinquished the second-floor gallery for the care of wounded soldiers. Whitman had long admired the architecture of its Doric façade, describing it as "that noblest of Washington buildings" ( $M D W 10)$. Throughout the nineteenth century the galleries displayed models submitted by inventors alongside 
their patent applications, and provided exhibition space for artifacts of national significance..$^{55}$ Commissioner Henry Ellsworth described the National Gallery housed within the Patent Office as "a perpetual exhibition of progress and improvement. . . . Here the most beautiful specimens of the genius and industry of the nation will be found." ${ }_{56}$ Whitman was mesmerized by the "immense apartments . . . fill'd with high and ponderous glass cases, crowded with models in miniature of every kind of utensil, machine or invention it ever enter'd the mind of man to conceive; and with curiosities" (MDW 10).

A decade before the Civil War, the galleries housed a posthumous menagerie of natural history specimens. In 1836, Congress funded the U.S. Exploring Expedition (commonly known as the Wilkes Expedition after its commander, Charles Wilkes) to survey the Pacific Ocean and South Sea Islands. ${ }^{57} \mathrm{~A}$ corps of scientists-including naturalists, botanists, and taxidermists - collected specimens throughout the voyage. They gathered thousands of zoological and botanical artifacts, including two-thousand previously unidentified species, which founded the Smithsonian's natural history holdings. ${ }^{58}$

During the war, the Model Room contained an even stranger collection. The most severe casualties from second Bull Run, Antietam, and Fredericksburg were brought here. The sight of hospital cots scattered between the illuminated display cases created an eerie spectacle:

It was a strange, solemn and, with all its features of suffering and death, a sort of fascinating sight. . . . Between these cases are lateral openings ... and in these were placed the sick. . . . Many of them were very bad cases, wounds and amputations. . . . It was, indeed a curious scene at night, when lit up. The glass cases, the beds, the forms lying there, the gallery above, and the marble pavement under foot-the suffering, and the fortitude to bear it in various degrees ... sometimes a poor fellow dying, with emaciated face and glassy eye, the nurse by his side, the doctor also there, but no friend, no relative - such were the sights but lately in the Patent Office. (MDW 10-11)

This “curious scene," perhaps more than any other, haunted Whitman's hospital prose. Traces of these human specimens recur as ghostly imprints scattered throughout the Whitman canon. Their bodies recall the industrial models and zoological specimens that surrounded them, and preceded their occupation of this space. Their convalescence within the galleries foreshadows their potential afterlives, dismembered and stripped of flesh, in the Army Medical Museum. These soldiers died among strangers, with "no friend, no relative" to witness their final hours. Anonymity is central to their spectral magnetism. Throughout Whitman's war poetry and prose, the unknown soldier is an enduring figure of collective grief: "Unnamed, unknown, remain, and still remain, the bravest soldiers." ${ }^{59}$ How can we mourn the dead when "their very 


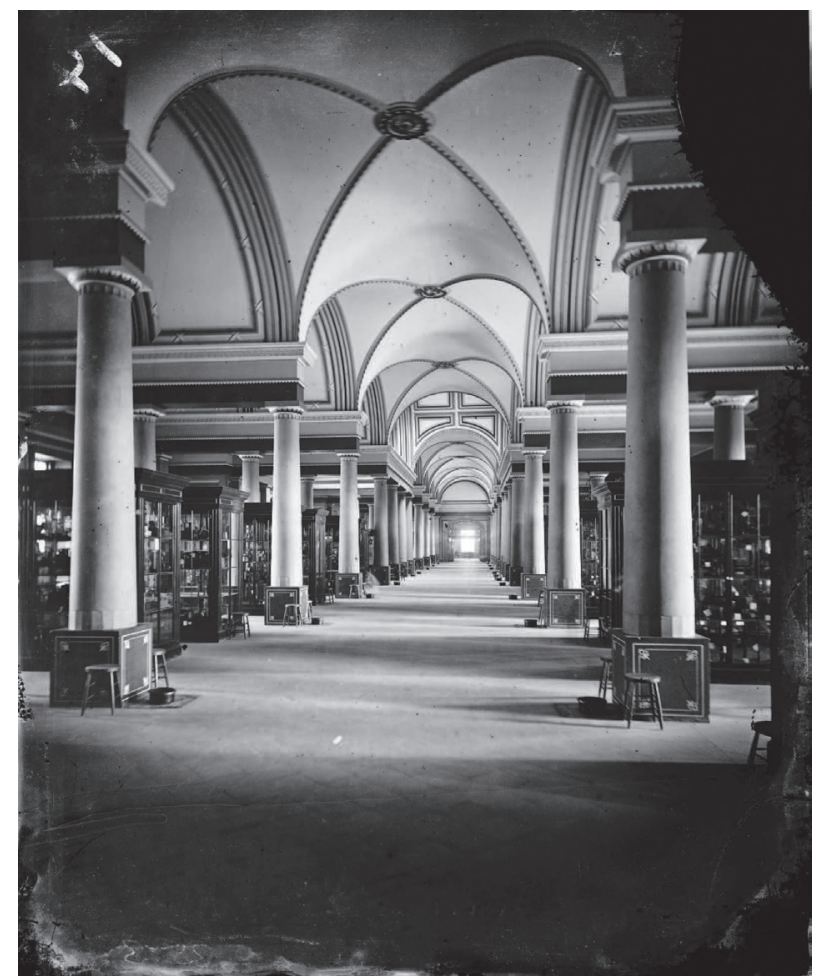

Figure 1. "Old Patent Office Model Room." Washington D.C., 1865. Courtesy of the Library of Congress, from the Brady-Handy Collection, Prints and Photographs Division.

names are lost," when their bodies remain unburied? (MDW 16). This is a central question of Memoranda, Specimen Days, and Drum-Taps, which the figure of the specimen attempts to reconcile. As a representative body capable of merging with others, who died similar deaths in similar places, the specimen allows the act of mourning to be unbroken by the limits of selfhood and otherness, known and unknown.

Within the corridors of the model room, Whitman's soldiers exist as uncanny doubles, haunted by past and future specimens (fig. 1). Initially, they are framed by the cabinets of curiosities that decorated the galleries. Two years later, at Lincoln's second inaugural ball, Whitman saw the scenes superimposed-revelers danced between unseen and uninvited guests, the ghosts of lost soldiers:

To-night, beautiful women, perfumes, the violins' sweetness, the polka and the waltz; then the amputation, the blue face, the groan, the glassy eye of the dying, the clotted rag, the odor of wounds and blood, and many a mother's son amid strangers, passing away untended there. (PW 1:95) 


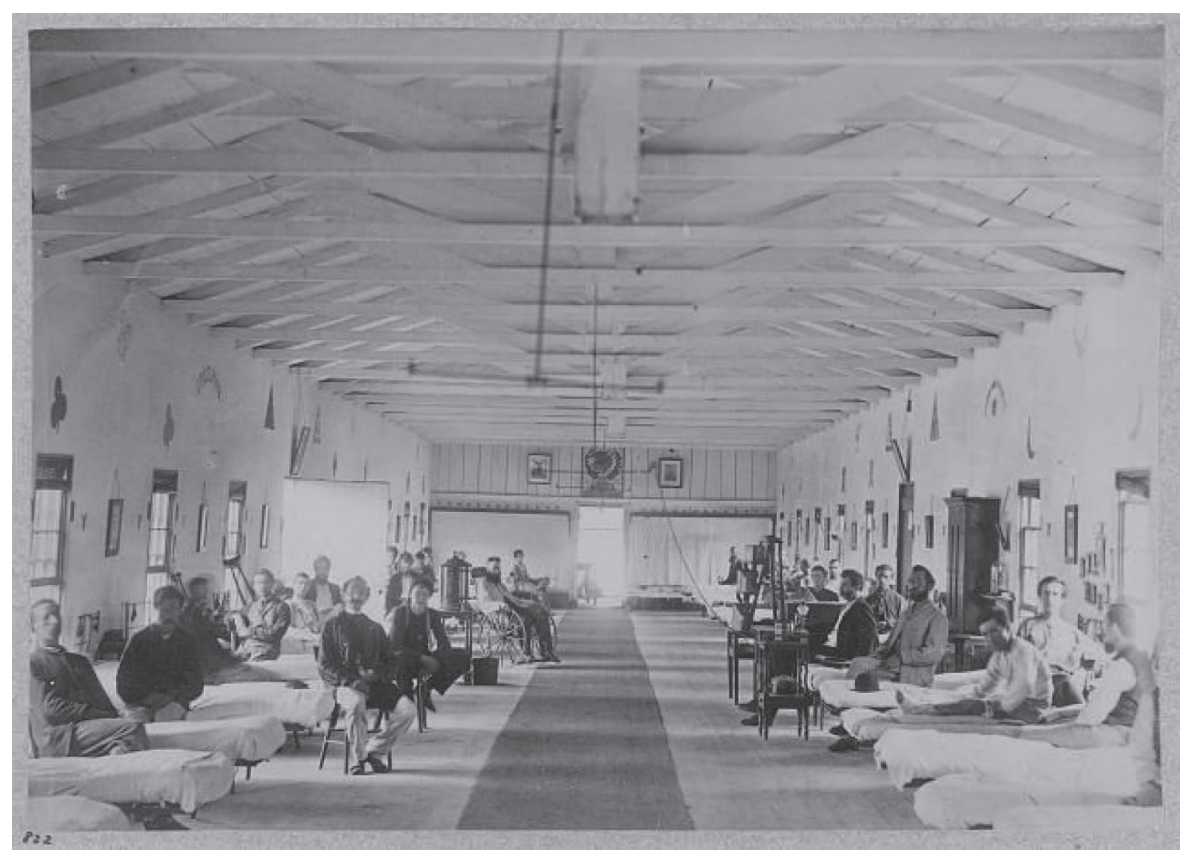

Figure 2. "Ward K, Armory Square Hospital, August 1865." Courtesy of the Library of Congress, Prints and Photographs Division.

These resurrected patients invade the present with phantasmal sensations. The ladies' perfumes are obscured by the "odor of wounds and blood"; the "violins" sweetness" is drowned out by the "groan[s]" of the dying. The inauguration is superseded by the illumined bodies reflected in the glass cabinets, their suffering rendering them somehow transcendent.

As a hallucinatory ghost, the afterimage mirrors the phantom pains experienced by many of the amputees Whitman attended. While the afterimage functions as the visual trace of a trauma one continues to see, the phantom limb embodies the absence of an entity one continues to feel. Whitman's sensory haunting demonstrates the physicality of mourning: it is inscribed upon the body. The past returns as physical sensation: sight, smell, and sound. The poet's specimen ghosts surround and consume him. They are not confined to the interiority of the mind.

After the Patent Office wards closed in March 1863, Whitman spent most of his time at Armory Square on the Mall (fig. 2). As he explained to his mother, "I devote myself much to Armory Square Hospital because it contains by far the worst cases, most repulsive wounds, has the most suffering \& most need of consolation" (Corr. 1:112). The following archival fragment invites the reader to see the wards through Whitman's eyes: 
Would you not like to see for yourself, Dear reader, some special ones of the cases among the hundreds I have met? Enter with me this long ward, look down its rows of cots, with their occupants stretching away each side. With the wide open aisle in the middle. Every one of these cots has its history-every case is a tragic poem, an epic, a romance, a pensive and absorbing book, if it were only written. ${ }^{60}$

Each "case" issues the invitation of a blank page. Collectively, they form a "pensive and absorbing book" - a spectral text that exists, as yet, only in the mind of its author and the bodies of its subjects. This representation of the convalescent body as an "absorbing book" portrays Whitman's war texts as sites of incorporation for the war's unwritten histories and unburied corpses. The book becomes a textual crypt that houses the specters of lost soldiers, allowing author and reader continued access to their afterlives. Whitman attests to the literary capacity for resurrection-the ability of words, however fragmented, to haunt.

\section{In Blooming Flesh}

The Army Medical Museum's first specimens were sourced from the same wards that Whitman frequented (fig. 3). Brinton recalled the severed limbs' transformation from "human fragments" into pathological artifacts: "I obtained ... amputated arms and legs from the Washington hospitals ... these [were] cleaned, prepared and mounted, and ... made their first appearance on the top of my desk" (PM 181-182). The curator's account of the specimen's journey from human appendage to medical waste to museum relic illuminates his memoir as a narrative of corporeal transference:

Any account of the Museum would be incomplete without some description of how ... they passed from their original possessors to the Museum. . . [T] he bones of a part removed would usually be partially cleaned, and then with a wooden tag and carved number attached, would be packed away in a keg, containing alcohol . . . sent to Washington and turned over to the Army Museum . . . so that they could take their place upon the shelves. (185-186)

Brinton's preservation compulsion was not only physical, but also textual. He meticulously archived the histories of his "objects": "The memoranda ... [were] forwarded to the Surgeon-General's Office, ... entered in the books of Histories of Specimens, preserved in the Museum" (186). The aesthetics of display were equally paramount. The curator designed glass cabinets modeled after those in his home office: "I was enabled ... to fit up good cases for the rapidly growing collection. The doors locked with bronze hands, which slid bolts at top and bottom." The latches are gilded reminders of the human bodies from which the enclosed skeletal fragments were sourced. These bones are further dehumanized by Brin- 


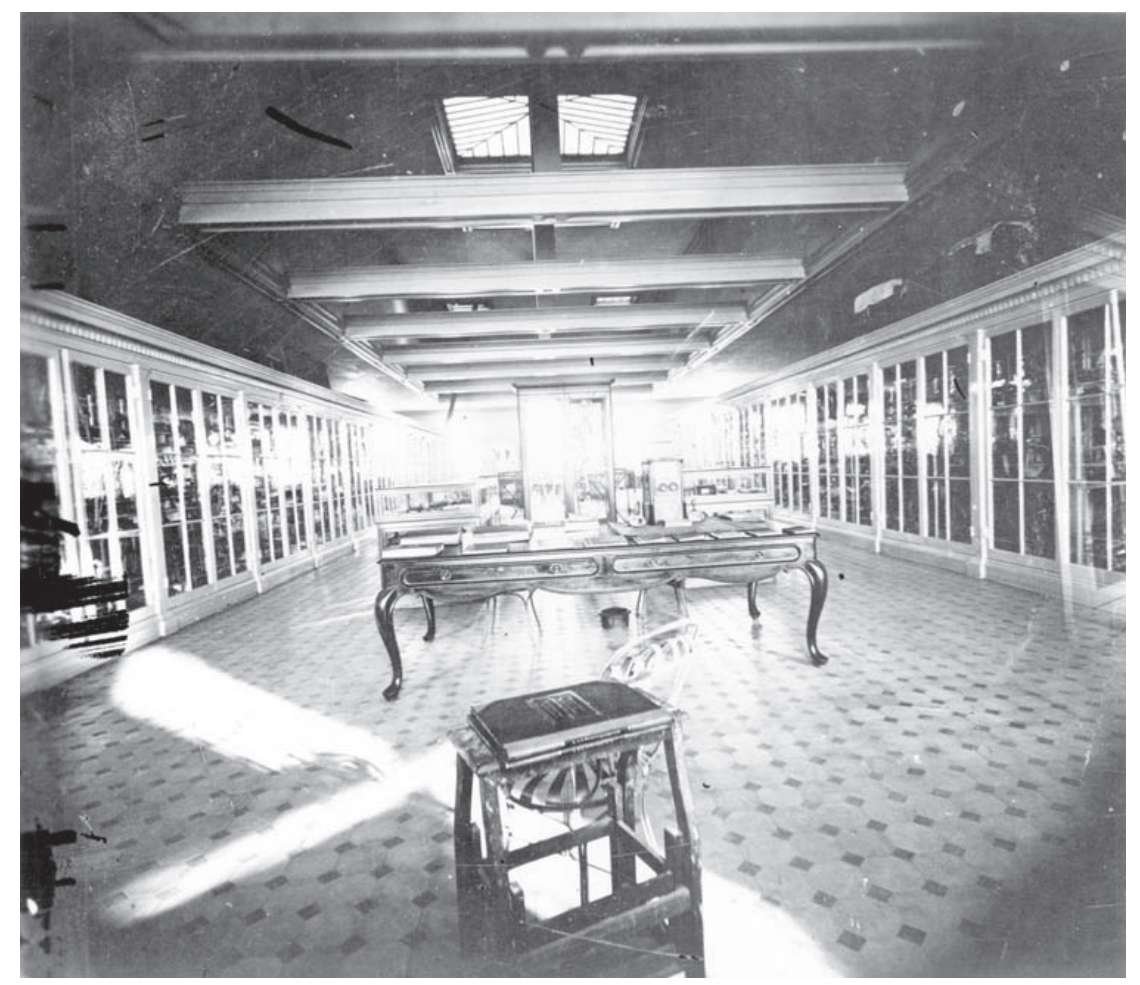

Figure 3. "Main Gallery, Army Medical Museum, 1867.” Photograph attributed to William Bell. Courtesy of the National Museum of Health and Medicine.

ton's invocation of human anatomy to describe the latches, but not the specimens themselves. Like Whitman, Brinton expressed post-bellum nostalgia for his cabinets and their contents: "not long ago, I saw my old cases, altered, yet the same, still standing in the Army Museum, containing so many of the specimens once so familiar" (185).

The curator's "search for specimens" led to many "strange scenes" of exhumation. "One such case" concerned the acquisition of "a remarkable injury of a lower extremity" (190). Brinton's efforts to secure the specimen were initially thwarted: "the man had died with the limb on and had been carefully buried by his comrades," who were determined to protect the corpse from disturbance. Unwavering in his determination, Brinton visited the "mess mates, explained my object," and "dwelt upon the glory of a patriot having part of his body at least under the special guard of his country" (PM 190).

Brinton not only convinced the soldiers to agree to the disinterment, but to carry out the act themselves: "the comrades of the dead soldier solemnly decided that I should have the bone for the good of 
the country, and in a body they marched out and dug up the body." The curator persuaded the fallen soldier's comrades with the Unionist lure of synecdochic glory: "a patriot" giving up "a part of his body . . . for the good of the country" (190-191). This logic demonstrates the uncanny duality of military bodies: the soldiers form a patriotic body that exhumes a corporeal one. The specimen assumes a life of its own, independent of the vanishing agency of its "original possessor" (185).

Brinton recorded the common drive of many amputees to revisit their lost parts: "officers and soldiers who had lost a limb by amputation would come to look up its resting place" (189). One particular incident recurs throughout the curator's published materials. Brinton recalled the following account of a soldier observing his own specimen:

On one occasion a man from the ranks demanded the return of a limb. . . He was informed that the member in question could not be given up. "But it is mine," said he, "part of myself," earnestly enforcing his claim, and his demand to the lay mind seemed reasonable. Yet to surrender a specimen was very much like yielding a principle. "Stop," said the quick-witted young assistant curator to the claimant, "for how long have you enlisted?" "For three years or the war." "Then," replied the official, "the contract is not yet terminated, come back at the end of the war or at the expiration of your three years' service and you can have your bone. In the meantime one detachment of you is stationed in this Museum on government duty, the other wherever you may be ordered." 61

This soldier resists the museum's doctrine of military possession, seeking to reclaim the limb as "his own property" (PM 190). The curator insists that his enlistment mandates governmental ownership over his entire body. One "detachment" remains "on duty" as medical spectacle stationed within the museum. The Union retains whatever "part" of the military body remains useful, irrespective of the psychological consequences. ${ }^{62}$

In contrast to Whitman's invocation of "specimens" as "active and breathing forms," Brinton constructs a cabinet of curiosities in which the lost object is permanently quarantined $(M D W 3)$. The Army Medical Museum operates as a site of false incorporation, where the "foreign body" is not "lodged within the subject," but encased forever in its foreignness, entirely other and inaccessible (Abraham and Torok, 174). As Lawrence Johnson explains, psychic "[i]ncorporation produces the gap in the psyche which Abraham and Torok have called the crypt, a place where the lost object is to be kept alive within the ego." ${ }^{63}$ The Army Medical Museum inverts incorporative mourning processes, creating a space where the detached object is kept dead, and externalized.

Following Lincoln's assassination, Ford's Theater was remodeled to install "long rows of glass cases, in which are exhibited to the glance of the curious the prepared specimens of anatomy." 64 The relocated museum opened on April 13, $1867 .{ }^{65}$ By the year's end, more than 6,000 
visitors had examined the collection. ${ }^{66}$ Given Whitman's fascination with war specimens and Lincoln's death scene, he may well have been among the throng of visitors. The following draft is, in all likelihood, a response to the Medical Museum:

The mouldering bones and dry skeleton or parts of the skeleton are all that is presented as Past History. But that is not Past History. The Past! The peoples of a hundred or a thousand, or ten or twenty thousand-yea fifty or a hundred thousand years ago, they too lived in blooming flesh, with sparking eyes and speaking lips, knew love, ambition, war!, perhaps even science the same as we do now. ${ }^{67}$

This fragment captures Whitman's fascination with the instability of history. In Specimen Days, the poet insists that "The real war will never get in the books"-or, in this case, onto the museum's shelves. These "dry bones" cannot resurrect the "blooming flesh" of lost soldiers. Even poetry can only capture fragmentary juxtapositions of suffering and tenderness: "the profuse beauty of the young men's hair damp with their spotted blood." 68

Despite his assertion that the traumas of war remain untranslatable, Whitman endeavored to construct a text that could offer, at least, a glancing approximation. He hoped that Memoranda would "furnish a few stray glimpses into . . . those lurid interiors . . . never to be fully convey'd to the future" (MDW5). Whitman's rhetoric reveals a resurrectionist desire to unearth the war's "untold" history, alongside a paradoxical sense that certain aspects of that history must remain "buried":

[T] he marrow of the tragedy concentrated in those Hospitals . . those forming the Untold and Unwritten History of the War. ... Think how much, and of importance ... has already been-buried in the grave, in eternal darkness! (MDW 5-6)

Given the publicity of the Army Medical Museum and its catalog, Whitman's anatomical metaphor alludes to The Medical and Surgical History of the War of the Rebellion. These six volumes contain summaries of over 6000 specimens, alongside casualty statistics, etchings, engravings, and photographs. Brinton worked exhaustively on the Surgical History until he was relieved from the Surgeon General's Office in 1864 (PM 169179). Similar in scope to nineteenth-century analyses of natural history collections, the compilers approached war as a human experiment that allowed researchers to accumulate unparalleled quantities of medical data ${ }^{69}$ As a counterpoint to this statistical analysis, Whitman describes the "marrow of the tragedy" as "buried" and "unwritten"-impossible to exhume either medically or poetically.

A letter from William O'Connor to Whitman (October 2, 1884) reveals that many years after the war, when the poet was residing at 
Camden in declining health, he remained interested in the contents of the Army Medical Museum and desired access to its archives:

I have been over today to the Surgeon General's office to see about data for you. ... I am afraid that the quest will be fruitless. The only matter they have is the Medical and Surgical History of the War, now in process of publication, what you want-i.e. hospital matter - will be in the third volume. ... I will go down tomorrow to the Medical Museum ... [and] talk with Dr. Wild, the librarian, and see if he can give me anything. I fear it is unlikely - the publications being inchoate. ${ }^{70}$

O'Connor's description of the archival material as "inchoate" echoes Whitman on the transience of war casualties. The quest to compile mortality figures had become a national obsession following the war. ${ }^{71}$ Whitman echoes this cultural anxiety surrounding the "unfound" dead, and questions the capacity of history, literature, or science to preserve their remains ( $M D W 56)$. Throughout the fluctuating post-bellum editions of Leaves of Grass, Whitman constructs a literary crypt that expands and contracts in an effort to house these diasporic ghosts.

\section{The Noblest Specimen}

Skeletal remains from at least four of Whitman's soldiers became artifacts in the Army Medical Museum. Lenore Barbian, Paul Sledzik, and Jeffrey Reznick, former Curators at the National Museum of Health and Medicine, recently published research identifying four human specimens that originated from soldiers attended by Whitman. ${ }^{72}$ This forensic revelation exposes striking intersections between Whitman's "specimen cases" and Brinton's anatomical curiosities. All four were submitted by Dr. D. Willard Bliss, chief surgeon at Armory Square Hospital, whom Whitman described as "one of the best surgeons in the army." 73 Bliss reciprocally praised Whitman for his devotion to the wounded: "no one person who assisted in the hospitals during the war accomplished so much good to the soldier and for the Government as Mr. Whitman."74 Did Whitman know that remains of these soldiers were displayed in the museum? Did he visit them there? While we may never definitively answer these questions, we do know that divergent forms of preservation (textual and medical) intersected upon the bodies of these four men, who were nursed by Whitman in life and curated by Brinton after death.

Oscar Cunningham was shot in the right leg at the Battle of Chancellorsville on May 2, 1863. He was admitted to Armory Square on June 10, where the bullet was extracted on June $15 .{ }^{75}$ Shortly after Cunningham's arrival, Whitman observed, "I thought he ought to have been taken to a sculptor to model for an emblematic figure of the 
west, he was such a handsome young giant over 6 feet high. . . [H]e has suffered very much since - the doctors have been trying to save his leg but it will probably have to be taken off yet."76 Whitman's prediction proved accurate. Abscesses surrounded the incision, necessitating amputation at the thigh. Bliss performed the surgery on May 2, 1864, the anniversary of Oscar's initial wounding. ${ }^{77}$ Whitman mourned the deterioration of his "youthful physical manliness" over the course of that year:

I have just left Oscar Cunningham in a dying condition . . . he is all wasted away to a skeleton ... when he was first brought in, I thought him the noblest specimen of a young western man I had seen. ${ }^{78}$

Cunningham was still alive on May 5, when Bliss submitted his right femur to the museum, where it was cataloged as Surgical Specimen 2254 (fig. 4). Surviving records do not indicate whether the soldier was aware that his limb was donated. Although Bliss's letter suggests that he held out hope for the patient's recovery, Cunningham died on June $5,1864 .{ }^{79}$ The case history contains a haunting reflection on calcified traces of Cunningham's deterioration: "the new bone formation firmly retains the fragments, and is sufficiently rounded to indicate the lapse of considerable time." 80

Whitman memorialized Oscar Wilbur as "A New York Soldier" in Memoranda. Wilbur sustained a "compound fracture of the femur" at the Battle of Chancellorsville on May 3, $1863 .{ }^{81} \mathrm{He}$ lay unattended on the battlefield for ten days before he was finally evacuated to Aquia Creek Hospital, where he remained for a further 42 days before being transferred to Armory Square. According to Bliss's reports, he suffered from constant nausea and died of "exhaustion, July 31, 1863." 82 Whitman remembered him as a stoic, spiritual young man who reciprocated the poet's affections:

I have spent a long time with Oscar F. Wilber, Company G, One Hundred and Fiftyfourth New York, low with chronic diarrhœa, and a bad wound also. . . . He talk'd of death, and said he did not fear it. . . He behaved very manly and affectionate. The kiss I gave him as I was about leaving he return'd fourfold. ${ }^{83}$ (MDW 21)

As Drew Gilpin Faust has established, the concept of the Good Death was vital to mid-nineteenth-century mourning practices. A peaceful death was as significant as an honorable life, perhaps even more so, as it was believed to foreshadow the status of the soul in the afterlife. Deathbed vigils required the presence of familial witnesses to observe the transition of the dying spirit. The violent, often isolated, deaths of soldiers could not have been further removed from these ars moriendi 


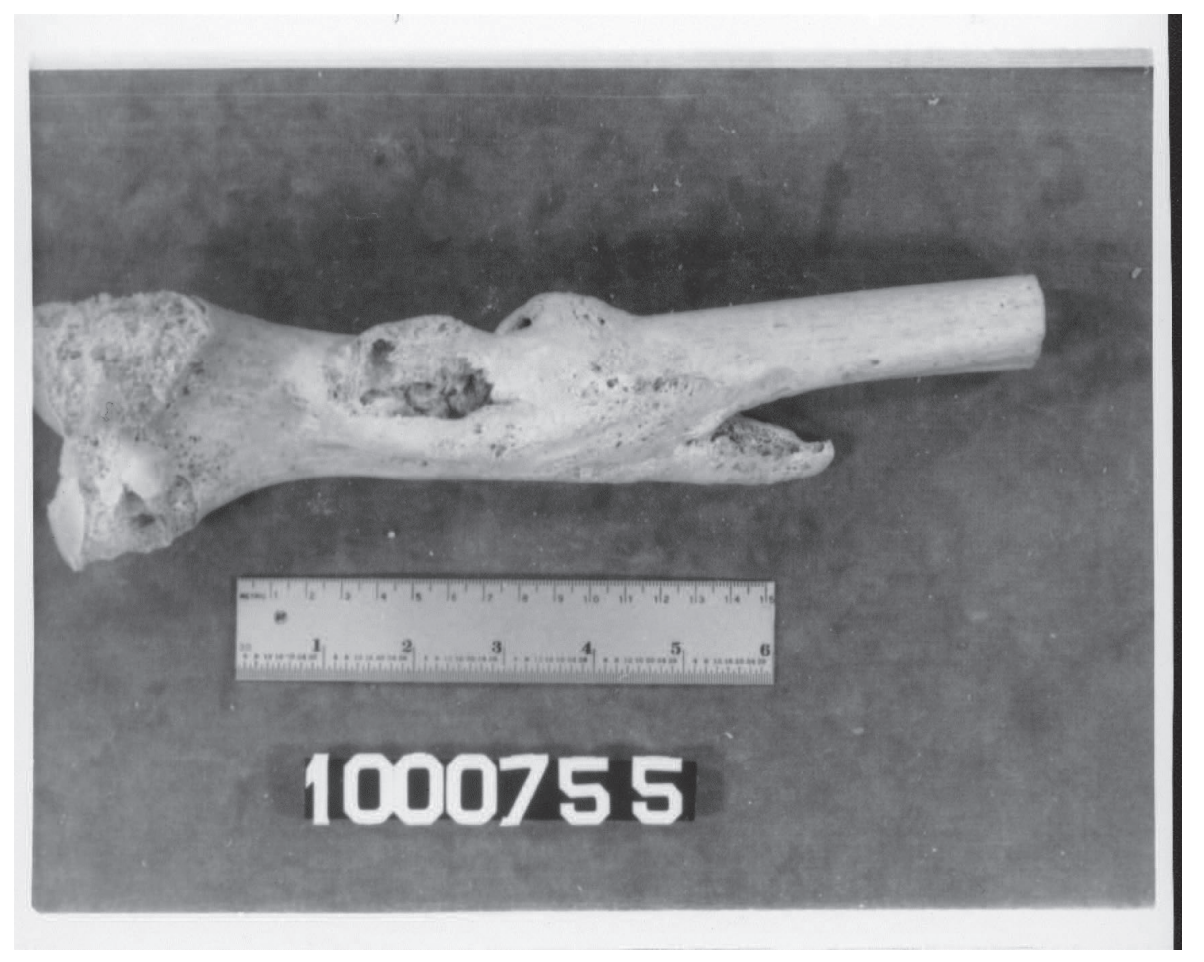

Figure 4. The lower right thigh bone of Oscar Cunningham. Courtesy of the National Museum of Health and Medicine.

rituals (Faust 7-10). Whitman ensured that his specimen-soldiers did not "die among strangers without having one at hand who loved ... [him] dearly." 84 The poet's deathbed presence allowed him to act as a surrogate mourner, to receive the soldier's "dying kiss." Oscar Wilbur died "a few days after" this encounter with Whitman (MDW 21). His right femur was posthumously amputated for the purpose of donation to the museum, where it became Surgical Specimen 1534 (fig. 5).

Whitman's most medically famous specimen was John Mahay, who was shot in the groin at the second battle of Bull Run on August 29, 1862. He was treated at Armory Square, where Whitman often visited him. Upon hearing of Mahay's unusual wound, Brinton personally interviewed the soldier. He kept a detailed account of Mahay's symptoms, including the passage of bone fragments through his urethra. Mahay died on October 24, 1864. During the autopsy, several urinary stones were removed from his bladder and cataloged as Surgical Specimen 2567 (fig. 6). ${ }^{85}$ Whitman memorialized the tragic narrative of Mahay's life and death in Memoranda: 


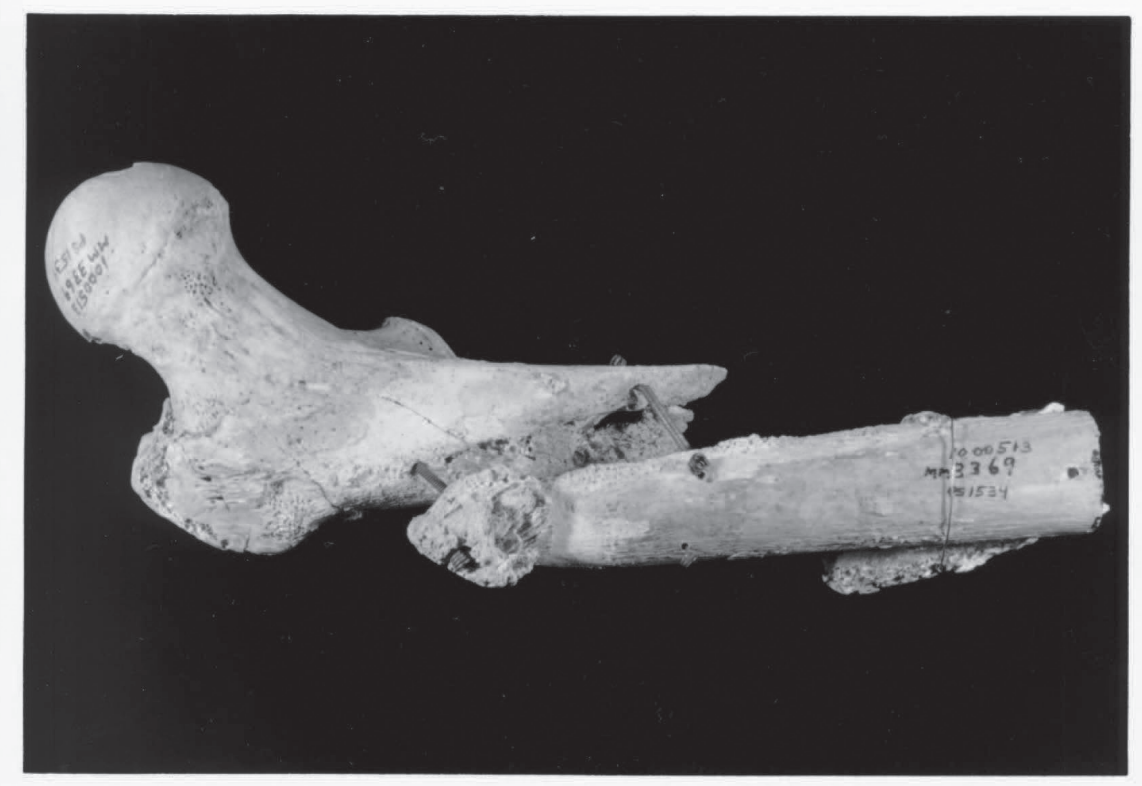

Figure 5. The upper right thigh bone of Oscar Wilbur. Courtesy of the National Museum of Health and Medicine.

Well, poor John Mahay is dead. . . . His was a painful and long lingering case. ... The bladder had been perforated by a bullet going entirely through him. ... Poor Mahay, a mere boy in age, but old in misfortune. He never knew the love of parents, was placed in his infancy in one of the New York charitable institutions, and subsequently bound out to a tyrannical master . . the scars of whose cowhide and club remained yet on his back. ... He found friends in his hospital life, and, indeed, was a universal favorite. $\mathrm{He}$ had quite a funeral ceremony. (37)

After enduring years of abuse, Mahay found a familial community in the ward. Posthumously, he attained medical notoriety. Unlike Whitman's other specimens, who were relegated to mere statistics, Mahay's unique wound earned a detailed description in the Medical and Surgical History, including graphic illustrations. The entry includes statements from both Bliss and Brinton, documenting the extent of the patient's suffering. Brinton observed, "[he] complains of pain at the anterior wound when he draws a long breath, and of constant pain in the glans penis." Bliss stated, simply, "he has never been perfectly free from pain." 86

On March 25, 1865, Frank H. Irwin sustained a gunshot wound in the left knee at the Battle of Fort Fisher. Three days later he was transferred to Armory Square, where Bliss amputated his leg on April 14. Assistant Surgeon M. J. Munger submitted his femur to the mu- 


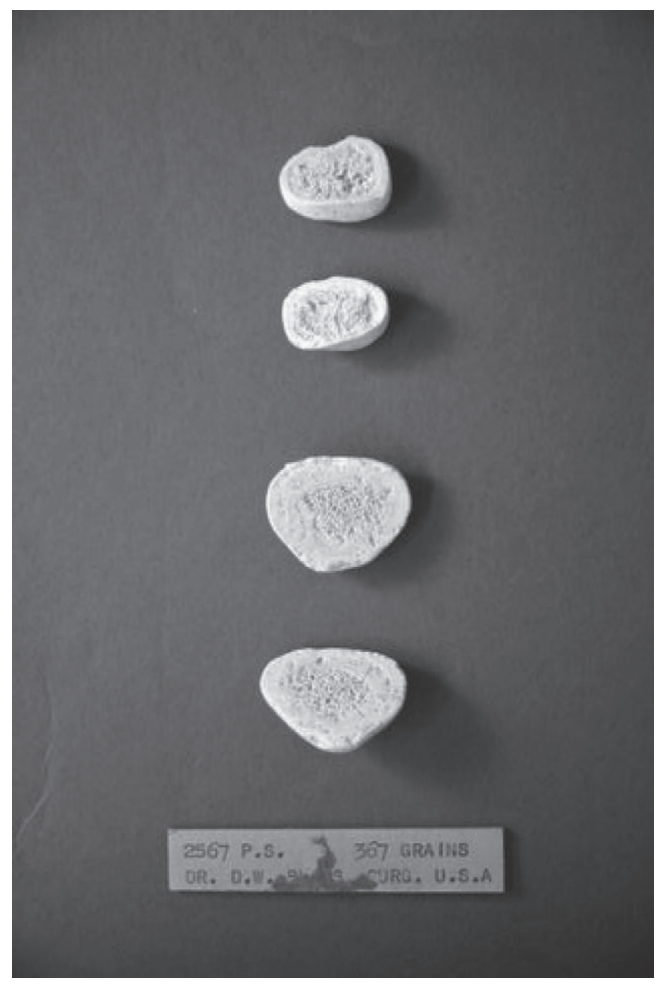

Figure 6. Urinary stones removed from the bladder of John Mahay. Courtesy of National Museum of Health and Medicine.

seum two days later. ${ }^{87}$ The bone was cataloged as Surgical Specimen 4077 (fig. 7). ${ }^{88}$ This medical narrative offers no insight into the soldier's experience of surgery or its aftermath. Like Cunningham, Irwin was still alive when his specimen was submitted. He died on May 2, 1865, following a severe pyaemia infection. ${ }^{89}$

In stark contrast to the neutrality of his medical history, Whitman recorded the tragic details of Irwin's demise under the heading "Death of a Pennsylvania Soldier." This entry reprints his condolence letter to Irwin's mother, words of comfort from a "casual friend that sat by his death bed":

[W] hat I saw of him here, under the most trying circumstances, with a painful wound, and among strangers, I can say that he behaved so brave, so composed, and so sweet and affectionate, it could not be surpass'd. ... I thought perhaps a few words, though from a stranger, about your son, from one who was with him at the last, might be worth while, for I loved the young man, though I but saw him immediately to lose him. (MDW 51) 


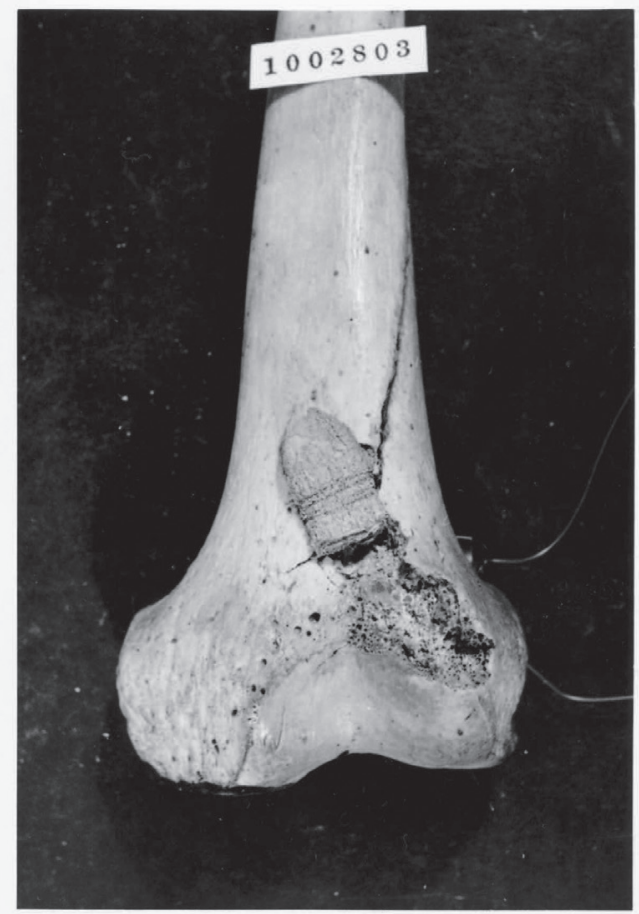

Figure 7. The lower left thigh bone of Frank Irwin. Courtesy of the National Museum of Health and Medicine.

Whitman's deathbed vigils demonstrate the capacity of strangers to form a binding affiliation with the dying, to mourn their passing even in the absence of personal history. The neglected symbol of the specimen in Whitman's writing reveals volumes about the intimacy of mourning strangers in nineteenth-century America. Moving beyond a necrophilic attachment to the corpse, the specimen recalls the allure of the phantom limb: an entity felt most acutely in its vacancy. As a signifier of embodied mourning, it traces connections that remain impossible to sever.

Whitman and Brinton offer convergent histories of the war's strange cases and dual bodies: military and corporeal, phantom and physical. Brinton's specimens are remnants of a fractured army, reconfigured within the museum to demonstrate the enduring coherence of the union. Whitman insists upon the continual erotic relevance of absent bodies and their abandoned parts. His specimens are textually entombed, a synecdochic representation of bodies that eluded burial. In contrast, Brinton's specimens are perpetually unburied, preserved behind glass cases. Yet, 
both poetic and surgical collections insist that the union endures, in spite of its wounds. The sutured democratic nation absorbs its "rejected members" - in Whitman's words, it "contain[s] multitudes." ${ }^{0}$ When Whitman writes of a specimen, he articulates a physical, psychological, and often sexual connection to another human being. The Whitmanian body is more than the sum total of its parts, and the dismembered part is therefore more than the subtraction of its original whole. The body $i$ s the soul, and the amputated limb retains a trace of the spirit that inhabited the living form, intact.

The museum's shelves and book's pages display carefully preserved afterlives of science and spirit. Brinton insisted that the museum was not merely a cabinet for war curiosities, but a national medical legacy: "[the] foundation, of a great National Surgical and Medical Museum, was not for the collection of curiosities, but for the accumulation of objects and data of lasting scientific interest" (PM 186). Yet, as the curator's account of one soldier's attempted repossession demonstrates, these specimens are more than clinical "objects." The public display of human remains elicited traumatic reverberations in both soldiers and civilians. Washington writer Mary Clemmer Ames described the exhibit's harrowing resonance: "to the unscientific mind, especially to one still aching with the memories of war, it must ever remain a museum of horrors" (477). While the museum's twenty-first century incarnation attests to the success of Brinton's project, contemporary accounts show that nineteenth-century audiences experienced dissonant affective responses to the collection.

Whitman's fascination with amputation paralleled his own desire to resurrect poetic incarnations of his lost specimens. Nostalgic longing and phantom limb both represent the irreconcilability of the past embodied within the subject. For Whitman, mourning is an ongoing attachment that transcends the physical presence of the body. The poet demonstrates an open-ended, queer hospitality to soldiers' "sensory ghosts" and their perpetually open wounds. ${ }^{91}$ The lingering influence of these absent limbs upon survivors and scientists frames the aftermath of amputation as a form of haunting that beset not only amputees, but also their carers, doctors, collectors and voyeurs. These lost members possess their own afterlives, independent of the bodies they left behind.

University of Sydney 


\section{NOTES}

1 In a letter to his mother dated December 29, 1862, Whitman states that he arrived in Falmouth on December 19 and returned to Washington on December 28. The Correspondence, ed. Edwin Haviland Miller (New York: New York University Press, 1961), 1:59. Hereafter, Corr. The letter is also available on the Walt Whitman Archive (whitmanarchive.org).

2 Whitman's hospital work "exposed him to dysenteries and horribly infected wounds. As a result, a bad infection in one hand climbed up into his shoulder, and he became beset by chronic headaches and fevers" (Caleb E. Finch, "Aging, Inflammation and the Body Electric," Deedalus 135 [Winter 2006], 68). By the spring of 1864, doctors advised Whitman to avoid the hospitals, following symptoms of weakness and cranial pressure. In June of that year Whitman returned to Brooklyn, where he convalesced for six months. In a letter to William O'Connor dated July 5, 1864, he wrote "My physician thinks that time, with the change of locality \& my own recuperative power, will make me well, but says my system is probably saturated with the virus of the hospitals \&c which eludes ordinary treatment" (Corr. 1:236.). Confirming the depth of his attachment to the soldiers, in 1865 Whitman returned to Washington for the duration of the war and its aftermath. Like many of the men he attended, the poet would never entirely recover from the traumas of war, both physical and psychological. At age 55, he suffered a stroke that partially paralyzed his left side. While his health progressively declined, the poet continued to exhaustively revise Leaves of Grass. Less than a year after the publication of the final edition, Whitman died on March 26, 1892. A postmortem examination revealed that he had long suffered from tuberculosis, most likely contracted in the Civil War hospitals. See Jerome Loving, Walt Whitman: The Song of Himself (Berkeley: University of California Press, 1999), 479.

3 Walt Whitman, Memoranda During the War (Camden: Author's publication, 18751876), 27. Hereafter, $M D W$. Available on the Walt Whitman Archive (whitmanarchive. org).

4 For an overview of sentimental mourning rituals, see Mary Louise Kete, Sentimental Collaborations: Mourning and Middle-Class Identity in Nineteenth-Century America (Durham: Duke University Press, 2000); and Dana Luciano, Arranging Grief: Sacred Time and the Body in Nineteenth-Century America (New York: New York University Press, 2007). Adam C. Bradford's dissertation explores Whitman's Drum Taps as a "material text capable of allowing a grieving public readership to reconnect with and successfully mourn their dead" "CCommunities of Death: Walt Whitman, Edgar Allan Poe, and the Nineteenth-Century American Culture of Mourning and Memorializing," Ph.D. Dissertation, University of Iowa [Ann Arbor: ProQuest, 2010, Publication No. 3422118], v). On the rise of spiritualism, see Molly McGarry, Ghosts of Futures Past: Spiritualism and the Cultural Politics of Nineteenth-Century America (Berkeley: University of California Press, 2008). On shifting attitudes towards the human cadaver, see Gary Laderman, The Sacred Remains: American Attitudes toward Death, 1799-1883 (New Haven: Yale University Press, 1996).

5 Throughout the nineteenth century, when anatomical specimens were in high demand but notoriously difficult to acquire, a black market trafficked in human remains. Medical body snatching was rampant in antebellum America. Whitman's revulsion toward the practice was captured in "The Eighteenth Presidency" (1856), a political tract that included "body-snatchers" alongside "robbers, ... murderers, ... disunionists ... [and] slave catchers" in a catalog of "dictators" who were "poisoning the politics of these states" (Notebooks and Unpublished Prose Manuscripts, ed. Edward 
F. Grier [New York: New York University Press, 1984], 6:2123. Hereafter, NUPM). Whitman was certainly not alone in his revulsion toward medical exhumation. The period between 1765 and 1855 saw at least seventeen anti-dissection riots, including the notorious New York Doctor's Mob of 1788. See Michael Sappol's cultural history of anatomical dissection, $A$ Traffic of Dead Bodies: Anatomy and Embodied Social Identity in Nineteenth-Century America (Princeton: Princeton University Press, 2002).

6 Civil War photographers depicted highly aestheticized, even staged images. Mark S. Schantz has analyzed the conformity of battlefield images with visual conventions of nineteenth-century photography. Corpses were often rearranged to create more arresting scenes. Living soldiers were sometimes coaxed into posing as dead. See Awaiting the Heavenly Country: The Civil War and America's Culture of Death (Ithaca: Cornell University Press, 2008), 184. See also: Timothy Sweet, Traces of War: Poetry, Photography and the Crisis of the Union (Baltimore: Johns Hopkins University Press, 1990), 107-137; Max Cavitch, American Elegy: The Poetry of Mourning from the Puritans to Whitman (Minneapolis: University of Minnesota Press, 2007), 239-240.

7 Whitman, NUPM, 2:504; Whitman, MDW, 27.

8 Oxford English Dictionary.

9 Freud, "Mourning and Melancholia," in On Metapsychology: The Theory of Psychoanalysis, ed. Albert Dickson and Angela Richards, trans. James Strachey (New York: Penguin, 1991), 262. Hereafter, $M M$.

10 Whitman, November Boughs, in Walt Whitman: Poetry and Prose (New York: Library of America, 1982), 1214, emphasis mine. Hereafter, PP.

11 Freud and Breuer, Studies on Hysteria, ed. and trans. James Strachey (New York: Basic Books, 1957), 221.

12 John H. Brinton, Personal Memoirs of fohn H. Brinton, Major and Surgeon, 1861-65 (New York: Neale Publishing, 1914), 180. Hereafter, PM.

13 Brinton, PM, 186; Mark Seltzer, "Wound Culture: Trauma in the Pathological Public Sphere," October 80 (Spring 1997), 3.

14 Nancy Cervetti analyzes the catastrophic consequences of the use of Minié balls as standard ammunition: "Before the war, because the traditional smoothbore musket had a maximum range of about 250 yards and an effective range of about 80 yards, close-order formation was necessary to concentrate the firepower of such inaccurate weapons. In 1848, however, Claude E. Minié invented a spinning conical bullet; then James $\mathrm{H}$. Burton made a cheaper and better version. These bullets not only increased the already high number of casualties, but also exacerbated the kind and extent of the physical injury and pain. . . . Because the soft lead flattened and broke apart upon hitting the human body, the destruction of tissue, bone, cartilage, and vein was massive" (S. Weir Mitchell, 1829-1914: Philadelphia's Literary Physician [University Park: Pennsylvania State University Press, 2012], 81).

15 Sweet has discussed Whitman's use of synecdoche in Memoranda and Drum-Taps, "in which a single event or experience replaces the whole of the war" (48).

16 Memoranda During the War was incorporated (with some changes) into Specimen Days, leaving much of the autobiographical narrative disproportionately devoted to the war years. 
17 Feldman reads Whitman's prose as "of a piece with the fragmenting and objectifying force of the museum's displays. The war along with Whitman's particular mode of representation turned the bodies of soldiers into objects. . . [S] ome of the order Whitman attains in his representation of the hospitals is produced by leaching the body of its individuality and condensing the wounded soldiers into types, specimens, and cases" ("Remembering a Convulsive War: Whitman's Memoranda During the War and the Therapeutics of Display," Walt Whitman Quarterly Review 23 [Summer 2005], 15-16). Conversely, Katherine Kinney articulates a fundamental distinction between Whitman's literary treatment of wounded soldiers and the museum aesthetic, which she links with the grotesque: "[t] he withering of flesh and the objective display of the museum mark precisely this loss of sensuality - a loss countered by the 'bodily excess' of Whitman's war prose in which injury and his response to it, including writing, remain sensuous human activity" ("Making Capital: War, Labor, and Whitman in Washington, D.C.," in Breaking Bounds: Whitman and American Cultural Studies, ed. Betsy Erkkila and Jay Grossman [New York: Oxford University Press, 1996], 174).

18 "Re-Collecting Soldiers: Walt Whitman and the Appreciation of Human Value," Walt Whitman Quarterly Review 27 (Winter 2010), 128, 135.

19 Michael Moon reads Whitman's intimacy with these convalescent soldiers as a form of corporeal mourning through which the wounded body becomes erotically charged. Rather than a focus on partiality as deficiency, Moon advocates for an understanding of "bodily abundance" and opportunities for "rememberment" in Whitman's war prose, where "loss is not lost." See "Memorial Rags" in Professions of Desire: Lesbian and Gay Studies in Literature, ed. George Haggerty and Bonnie Zimmerman (New York: MLA, 1995), 233-240.

20 Kinney has discussed the influence of museum aesthetics on Whitman's war prose: "The crude example of the Army Medical Museum proved itself to be only a curiosity. It may perhaps have been an intermediate gesture, a necessary demonstration of the government's ability to control, order, and enumerate the wounded and the dead in the immediate aftermath of the war. But it offers at least a suggestive explanation for why Whitman would claim again and again that his war prose was without literary design. These memoranda are not formal systems, he insists, but haphazard, random jottings, without any of the mediating gesture of poetry or narrative" (185). I agree that Whitman's specimens resist categorization (they are elusive, "otherworldly" beings, for all the poet's attempts to narrate their commonalities). I also read this as a response to the medical classification represented in the Army Medical Museum. However, Kinney's dismissal of the museum as a "crude" and fleeting "curiosity" is problematic, if for no other reason than the fact that the museum remains open to this day, and currently displays hundreds of Civil War specimens, including the remains of soldiers nursed by Whitman.

21 Walt Whitman, Leaves of Grass (Philadelphia: McKay, 1891-2), 408. Hereafter, LG 1891. Available on the Walt Whitman Archive (whitmanarchive.org).

22 Cathy Caruth, Unclaimed Experience: Trauma, Narrative, and History (Baltimore: Johns Hopkins University Press, 1996), 4.

23 Sigmund Freud, Beyond the Pleasure Principle, in On Metapsychology: The Theory of Psychoanalysis (New York: Penguin, 1991), 289. Hereafter, BPP.

24 Approximately 60,000 amputations were performed during the Civil War, more than during any other war in which the United States has been involved. See Laurann Figg and Jane Farrell-Beck, "Amputation in the Civil War: Physical and Social Dimen- 
sions," Fournal of the History of Medicine and Allied Sciences 48 (1993), 454. Silas Weir Mitchell treated Whitman for paralysis resulting from a stroke in 1873. In his daybook entry for April 18, 1878, Whitman recorded his initial consultation with the renowned neurologist (Charles E. Feinberg Collection, The Library of Congress). Brinton and Mitchell were both active members of the College of Physicians of Philadelphia, and they maintained close personal and professional alliances.

25 S. Weir Mitchell, "Phantom limbs," Lippincott's Magazine of Popular Literature and Science (1871), 8:563-569. Hereafter, "Phantom Limbs."

26 On Whitman's relationship with Lewy Brown, see Jonathan Katz, Love Stories: Sex Between Men Before Homosexuality (Chicago: University of Chicago Press, 2001), 152-156; and Robert Roper, Now the Drum of War: Walt Whitman and his Brothers in the Civil War (New York: Walker, 2008), 254-255.

27 Walt Whitman, Leaves of Grass (New York: 1867), 33a. Hereafter, LG 1867. Available on the Walt Whitman Archive (whitmanarchive.org).

28 Michael Moon, Disseminating Whitman: Revision and Corporeality in Leaves of Grass (Cambridge: Harvard University Press, 1991), 174.

29 Michel Foucault, The History of Sexuality, Volume 1 (New York: Vintage, 1990), 43 (emphasis mine).

30 Sedgwick, Epistemology of the Closet (Berkeley: University of California Press, 1990), 236.

31 Hans Fluck and Rita Jaspersen-Schib, Medicinal Plants and their Uses, trans. J.M. Rowson (London: W. Foulsham, 1976), 32.

32 Quoted by Gary Schmidgall in Walt Whitman: A Gay Life (New York: Dutton, 1997), 70.

33 Maria Farland, "Decomposing City: Walt Whitman's New York and the Science of Life and Death," English Literary History 74 (2007), 818.

34 Nicholas Abraham and Maria Torok, "Mourning or Melancholia: Introjection versus Incorporation," in The Shell and the Kernel: Renewals of Psychoanalysis, ed. and trans. Nicholas T. Rand (Chicago: University of Chicago Press, 1994), 125-139.

35 Christopher Peterson, Kindred Specters: Death, Mourning and American Affinity (Minneapolis: University of Minnesota Press, 2007), 20.

36 Whitman, MDW, 5; Jacques Derrida, The Work of Mourning, ed. Pascale-Anne Brault and Michael Naas (Chicago: University of Chicago Press, 2001), 159. Hereafter, $W M$.

37 Jacques Derrida, Aporias, trans. Thomas Dutoit (Stanford: Stanford University Press, 1993), 61-62.

38 Robert Leigh Davis describes the hospitals' significance for Whitman as a "convalescent democracy": "a democracy based not on closure but on liminality, not on a binary structure of separate spheres but on a convalescent structure of crossing and suspense" (Whitman and the Romance of Medicine [Berkeley: University of California Press, 1997], 5-6).

39 Whitman to Louisa Van Velsor Whitman, September 8, 1863, Corr. 1:145-146. 
40 As Betsy Erkilla observes, Whitman substantively altered the notebooks before publishing them as Memoranda and later Specimen Days. See Whitman: The Political Poet (New York: Oxford University Press, 1989), 207.

41 Sweet links the traumatic resonance of the notebooks "not so much because of their words, but because they bear traces of the violated human body which cannot be represented and thus must fail to become part of the public record of the war" (48).

42 Walt Whitman, “The Wound-Dresser," Leaves of Grass (Boston: James R. Osgood \& Co., 1881-1882), 241. Available on the Walt Whitman Archive (whitmanarchive.org).

43 Feldman has also observed correlations between acts of violence and writing in this passage: "Whitman described his writings as 'scratchings,' linking writing and wounding" (8).

44 Brinton, Circular letter, Surgeon General's Office, Washington, D.C., June 24, 1864.

45 Drew Gilpin Faust discusses the extraordinary practices embalmers employed to procure bodies and business: "Embalmers advertised both themselves and the process by exhibiting preserved bodies - often unknown dead simply collected from the field" (This Republic of Suffering: Death and the American Civil War [New York: Knopf, 2007], 95).

46 The move commenced in 1866, and the renovated museum opened to the public in 1867. It became an increasingly popular Washington landmark throughout the later nineteenth century. See Michael Rhode, "An Army Museum or a National Collection? Shifting interests and fortunes at the National Museum of Health and Medicine," Medical Museums: Past, Present, Future, ed. Samuel J.M.M. Alberti and Elizabeth Hallam (London: Royal College of Surgeons of England, 2013), 190.

47 The phrase "rejected members" is Whitman's: "One man is shot by a shell, both in the arm and leg-both are amputated - there lie the rejected members" (MDW 15). The phrase "mutilated limbs" is Brinton's: "It was hard enough to be worked day and night in those great surgical emergencies, accompanying fierce and protracted battles, and it really seemed unjust to expect the rough preparation, necessary to preserve for the Museum, the mutilated limbs" (PM 187).

48 Oliver Wendell Holmes, "The Human Wheel, Its Spokes and Felloes," Atlantic Monthly (May 1863), 567-568.

49 Guy R. Hasegawa, Mending Broken Soldiers: The Union and Confederate Programs to Supply Artificial Limbs (Carbondale: Southern Illinois University Press, 2012), 2.

50 Antebellum Americans employed provocative terms to describe the exhumation of human remains for medical experimentation. Anti-dissection protesters commonly referred to the practice as "bodysnatching," while corpse-seeking thieves, in an effort to elevate the rhetoric of disinterment, labeled themselves "resurrectionists." See David C. Humphrey, "Dissection and Discrimination: The Social Origins of Cadavers in America, 1760-1915," Bulletin of New York Academy of Medicine 49.9 (1973), 823.

51 On December 29, 1862, Whitman wrote to his mother: "One of the first things that met my eyes in camp was a heap of feet, arms, legs, \&c. under a tree in front of a hospital, the Lacy house" (Corr. 1:59).

52 As Feldman has observed, in Whitman's context the word "convulsion" "contains contradictory and divisive ideas. The prefix con-means together, while the Latin verb vellare means to pull or tear" (1). 
53 On this point, I am indebted to Michael Moon's essay, "Memorial Rags." Moon observes Whitman's resistance to "thinking of the deaths of others as the making deficient of our own bodies or body parts and resisting thinking of death as absolutely rupturing the possible erotic relation of a living person to a dead one" (236).

54 Walt Whitman, "My visits and distributions," holograph fragment, 1863, Berg Collection, The New York Public Library. Hereafter, "My visits."

55 Artifacts displayed included the Declaration of Independence, Benjamin Franklin's printing press, Egyptian mummies, and a mosaic of Pompeii (Bradford 135).

56 Henry Ellsworth, "Letter from Patent Office Commissioner Henry Ellsworth to Senator John Ruggles, December 18, 1840," National Portrait Gallery, Smithsonian Institution, Washington, D.C. (http://www.npg.si.edu/exhibit/pob/).

57 "United States South Seas Exploring Expedition (aka the Wilkes Expedition), 1838-1842," Harvard University Libraries Open Collections Program (http://ocp. hul.harvard.edu/expeditions/wilkes.html).

58 As Nathaniel Philbrick has established, "without the U.S. Exploring Expedition, there might never have been a national museum in Washington, D.C." In addition to the Smithsonian, "the U.S Botanic Garden, the U.S. Hydrographic Office, and the Naval Observatory all owe their existence, in varying degrees, to the expedition" ("Young Ambition: Charles Wilkes' Antarctic Adventure," MHQ: Quarterly fournal of Military History 17 [Autumn 2004], 84).

59 Bradford has discussed the empathic function of anonymity as a vehicle for projection: "In the absence of markers of identity, the poetic soldiers became reflections of a reader's mind-constructions that were at the very least intimate mental projections from the reader's own consciousness, and likely corresponded to actual individuals in the material world with whom the reader could now imaginatively connect" (139).

60 Whitman, "My visits.”

61 John H. Brinton, "Closing Address, Army Medical School," The fournal of The American Medical Association 26.13 (March 28, 1896), 602. A subdued version of this incident is related in Brinton's memoir (PM 190).

62 Soldiers experienced a diverse range of responses to encounters with their lost parts. On the other end of the spectrum, Union General Daniel Edgar Sickles, wounded at Gettysburg, donated his amputated leg to the museum, and made an annual pilgrimage to visit the specimen on the anniversary of his injury. Brinton recalled this anecdote in his 1896 address to the Army Medical School: "Occasionally it would happen that a specimen would be contributed to the museum by its former owner. No. 1335, resulting from a leg crushed by a twelve-pound shot at Gettysburg, and for which thigh amputation was performed, was forwarded to the Museum in an extemporized coffin on which was tacked a visiting card 'with the compliments of Major General D.E.S., United States Volunteers.' But not all were so compliant” (602).

63 Johnson, "Tracing Calculation (Calque Calcul) Between Nicolas Abraham and Jacques Derrida," Postmodern Culture 10.3 (2000), 2.

64 L. Bagger, "The Army Medical Museum in Washington," Appleton's fournal 9 (1873), 294. 
65 Mary Clemmer Ames, Ten Years in Washington: Life and Scenes in the Nation's Capital, As a Woman Sees them (Hartford: Worthington \& Co., 1873), 476. Brinton did not oversee the museum's relocation to Ford's Theatre. He was relieved of duty in the Surgeon General's Office in September 1864, a decision that he believed to be a consequence of his friendship with the recently cashiered Surgeon General William Hammond. See John S. Haller, Jr., Preface, Personal Memoirs of fohn H. Brinton, xxiv.

66 J.T.H. Connor and Michael Rhode, "Shooting Soldiers: Civil War Medical Images, Memory, and Identity in America," Invisible Culture 5 (2003), 5.

67 Undated draft fragment, Thomas Biggs Harned Collection of the Papers of Walt Whitman, Library of Congress.

68 Undated draft fragment, Washington and Brooklyn Hospital Notebook (1864), Thomas Biggs Harned Collection of the Papers of Walt Whitman, The Library of Congress.

69 Lenore Barbian, Paul S. Sledzik and Jeffrey Reznick, "Remains of War: Walt Whitman, Civil War Soldiers, and the Legacy of Medical Collections" Museum History fournal 5 (January 2012), 10.

70 Horace Traubel, With Walt Whitman in Camden (Boston: Small, Maynard \& Co., 1906), 1:178-179. Whitman probably wanted to include this material in November Boughs (1888), which included casualty statistics (PP 1233).

71 As Drew Gilpin Faust has established, statistics offered a mechanism for imposing order over immeasurable carnage (250-265).

72 I am indebted to the groundbreaking discoveries of these curators. Significantly, the relationship between Whitman and these specific specimens in the Army Medical Musuem has yet to be analyzed outside of a Museum Studies context. The authors confine their investigation to the soldiers' medical histories and Whitman's relationships with these four men; the correlations between Whitman and Brinton remain, until now, unexamined.

73 Whitman to Mrs. Irwin, May 1, 1865, Corr. 1:259.

74 Martin G. Murray, "Travelling with the Wounded: Walt Whitman and Washington's Civil War Hospitals," Walt Whitman Archive (whitmanarchive.org).

75 Memorandum by Willard Bliss, May 5, 1865, Otis Historical Archives, National Museum of Health and Medicine.

76 Oscar Cunningham's deterioration is narrated in a number of Whitman's letters from 1864: May 6, May 10, May 25, June 3, and June 7. On April 12, 1864, Whitman observed in his hospital notebook, "as I write this his leg is in a horrible condition, all livid \& swollen out of shape-the chances are against him, poor fellow." Thomas Biggs Harned Collection of the Papers of Walt Whitman, Library of Congress.

77 “Specimen No. 2254, Oscar Cunningham, Private, Co. J, 82 nd Ohio Infantry," memorandum by Willard Bliss, May 5, 1865, Otis Historical Archives, National Museum of Health and Medicine. Hereafter, "Specimen No. 2254."

78 Whitman to Louisa Van Velsor Whitman, June 3, 1864, Corr. 1: 229.

79 "Specimen No. 2254."

80 Ibid. 
81 "Specimen No. 1534, Oscar F. Wilbur, Private, Co. G, 154 ${ }^{\text {th }}$ New York Regiment," undated memorandum by Willard Bliss to John H. Brinton, Otis Historical Archives, National Museum of Health and Medicine.

82 Ibid.

83 Whitman misspells this soldier's last name, which is listed in hospital and museum records as Wilbur.

84 This letter to the family of Erastus Haskell, dated July 27, 1864, reflects the depth of the stranger's deathbed attachment. At the close, Whitman departs from convention and addresses the departed soldier directly: "So farewell, dear boy-it was my opportunity to be with you in your last rapid days of death - no chance as I have said to do anything particular, for nothing could be done-only you did not lay here \& die among strangers without having one at hand who loved you dearly, \& to whom you gave your dying kiss" (Corr. 1: 129).

85 "Notes on John Mahay, Surgical Specimen 2567," undated memorandum by John H. Brinton, Otis Historical Archives, National Museum of Health and Medicine.

86 G. A. Otis and D. L. Huntington, The Medical and Surgical History of the War of the Rebellion, vol. 2, part 3 (Washington, DC: Government Printing Office, 1883), 294.

87 "Specimen No. 4077, Frank H. Irwin, Corporal, 93 $3^{\text {rd }}$ Pennsylvania Infantry," memorandum signed by D. W. Bliss, April 17, 1865, Otis Historical Archives, National Museum of Health and Medicine. Hereafter, "Specimen No. 4077."

88 As Barbian, Sledzick, and Reznick have observed, the report is notably devoid of personal details compared to those written by Bliss, leading them to suspect that Munger was the author, although Bliss's signature appears on the report (22).

89 "Specimen No. 4077."

90 Walt Whitman, Leaves of Grass (New York: 1855), 55. Available on the Walt Whitman Archive (whitmanarchive.org).

91 Mitchell, "Phantom limbs," 8:563-569. 